\title{
Enkele opmerkingen over de diagnosticering van de stoornis en de prognosticering van het gevaar in de TBS
}

\author{
M. Otte
}

\section{Inleiding}

Het recht is gevoelig voor de mode en in zekere zin is dat terecht. Het recht vormt een spiegel van de samenleving en kent in dat opzicht een barometerfunctie inzake maatschappelijke zorgen en ontwikkelingen. Ook de TBS vormt een tijdgebonden instrument en dient daarom in het recht met een zekere zorg te worden gadegeslagen. Nog niet zo lang geleden werd deze maatregel veelvuldig opgelegd terzake van vermogensdelicten. Thans wordt de maatregel hoofdzakelijk opgelegd bij agressie- en zedendelicten. De TBS illustreert primair dat de veroordeelde het bewezen verklaarde feit niet of niet geheel kan worden toegerekend, dat hij behandeling behoeft alsmede dat de TBS mede de beveiliging van de samenleving dient. De strafrechter heeft voor dit soort verstrekkende beslissingen advies nodig vanuit de psychiatrische discipline. In de overwegingen van de strafrechter valt globaal een aantal criteria te ontwaren. Bij de verdachte moet sprake zijn van een stoornis, er moet gevaar zijn, tussen stoornis en delict enerzijds en tussen stoornis en gevaar anderzijds moet een oorzakelijk verband bestaan ${ }^{1}$, de veiligheid van de samenleving moet in het geding zijn en de maatregel dient tenslotte te voldoen aan proportionaliteits- en subsidiariteitsmaatstaven.

De kern van mijn betoog is dat de strafrechter met zeer grote omzichtigheid de adviezen van de gedragsdeskundige moet beoordelen en spaarzaam moet zijn met het opleggen of verlengen van de TBS.

* Vice-president Gerechtshof Arnhem

1 E.J. Hofstee, TBR en TBS, Arnhem 1987, p. 460. De psychische stoornis moet bestaan hebben tijdens het plegen van het feit (Hofstee noemt dit het gelijktijdigheidsverband). 


\section{De stoornis}

Problemen doen zich voor indien de strafrechter kennis neemt van ondoorzichtige adviezen over de aanwezigheid van een mogelijke stoornis. Indien verschillende psychiaters elkaar tegenspreken wordt het voor de strafrechter moeilijk om een keuze te maken. Waar de ene deskundige stelt dat zich bij verdachte een stoornis in de betekenisgeving voordoet, gepaard gaande met een ernstige stoornis in de zelfwaardering, waardoor het zelfbeeld vluchtig, ijl en niet verworteld is, komt de tweede deskundige tot het oordeel dat het voorgaande ten onrechte suggereert dat er sprake is van een persoonlijkheidsstoornis. Volgens deze contra-expertise zou er veeleer sprake zijn van een aanpassingsstoornis. Deze verschillen in diagnose leiden tot sterk verschillende adviezen. De strafrechter mag het vervolgens uitzoeken.

Regelmatig lees ik dat een verdachte een slecht contact heeft met de realiteit door het ontbreken van enig probleembesef, zelfinzicht en een fundamenteel gebrek aan empathische vermogens. Daarnaast zou bij dergelijke verdachten veelvuldig sprake zijn van een conflictueuze agressiehuishouding, met impulsiviteit en explosiviteit als uitingen daarvan.

Afgezien van het feit dat deze conclusies soms meer lijken te stoelen op de uiterlijke waarneming van de gepleegde feiten dan op een diepgaand psychiatrisch onderzoek, ben ik niet per definitie door dit type analyse overtuigd van een gebrekkige ontwikkeling van de onderzochte verdachte of zelfs van de aanwezigheid van een psychiatrische stoornis. Een antisociale persoonlijkheid wijst in ieder geval nog niet direct op een stoornis in psychiatrische zin. De diagnose van de gedragsdeskundige dat de verdachte niet gemotiveerd is voor enige behandeling, dat de kans op herhaling van soortgelijke strafbare feiten als bewezen verklaard, reëel is en dat voor verdachte een hechte structuur noodzakelijk lijkt, wijst ook niet per definitie in de richting van een psychiatrische setting, maar eerder in de richting van een vrijheidsbeneming van lange duur.

Terzake de diagnosticering door de gedragsdeskundige zou de strafrechter wellicht gebaat kunnen zijn bij het inschalen van de ernst van de stoornis aan de hand van de mate van integratie. Bij een neurose is de betrokkene licht tot matig geïntegreerd, terwijl een psychose daarentegen een sterke tot volledige desintegratie 
indiceert, maar wellicht mogelijk partieel (deels afgekapseld) van aard of wisselend in de tijd (in acute fasen). ${ }^{2}$

Regelmatig wordt de rechter geconfronteerd met gedragsdeskundigen die een antisociale persoonlijkheid schetsen, op grond waarvan een diepgaande behandeling noodzakelijk zou zijn. Bij tijd en wijle zou de indruk kunnen ontstaan dat uit een ernstig agressief en bedreigend delict de stoornis wordt geconcludeerd.

De strafrechter moet voortdurend voor ogen houden dat het strafrecht zich primair focust op de gepleegde daad (de gedraging) en de verantwoordelijkstelling daarvoor door de verdachte. Alhoewel in de psychiatrie dit uitgangspunt zal worden onderschreven, heeft het er soms veel van weg dat veeleer de persoon van de dader en in toenemende mate ook zijn gehele leefomgeving wordt gepsychologiseerd. Het risico is niet denkbeeldig dat in sommige gevallen het ziektebeeld en de daarmee gepaard gaande vertakkingen naar de gezins- en familieomstandigheden van de patiënt zodanig worden uitvergroot dat de loutere verantwoordelijkheid voor het delict uit zicht lijkt te verdwijnen. Wellicht verklaart die ontwikkeling ook de groeiende aandacht onder gedragsdeskundigen voor empirische aspecten, met name in de sfeer van de prognosticering. ${ }^{3}$

Twijfelachtig is of de psychologisering van met name de leefomgeving van de persoon van de dader de jurist in bepaalde strafzaken niet teveel afleidt van de wellicht ouderwets aandoende gedachte in het bewezenverklaarde te worden geconfronteerd met het kwade in een mens. Een gedragsdeskundige zal een misse daad veelal verklaren uit al dan niet aangeboren gedragskenmerken die na behandeling ofwel veranderbaar dan wel beheersbaar zijn. Het is de vraag of de gruwelijkheid van een daad de rechter niet te snel doet vermoeden dat er met de psyche van de verdachte wel iets goed mis moet zijn. Is het niet denkbaar dat dat vermoeden ontspringt aan ons fundamentele onvermogen om in de schaduwzijden van onze eigen ziel, laat staan van andermans ziel door te dringen? Anders denken lijkt in ieder geval een pretentie die haaks staat op de per definitie beperkte condities om in een rechtszaal tot een gelijkwaardige en diepgaande ontmoeting met de verdachte te geraken. Regelmatig vraag ik me af of de driften en neigingen van een verdachte juist níet moeten worden tegemoet getreden met een pretentieus behandelingsaanbod maar veeleer met een langere gevangenisstraf, waarbinnen zich

2 Zie P.C. Kuiper, Neurosenleer, Deventer 1978; G. Hutschemaekers, Neurosen in Nederland, dissertatie KUB, Nijmegen 1990.

3 A.W.M. Mooij, Schuld in strafrecht en psychiatrie, oratie RUU 1997. 
mogelijkheden tot een zekere behandeling kunnen voordoen. Ik kom daarop terug. Ik noemde de inzet van behandelaars pretentieus, aangezien ook zij - ondanks dat zij er voor doorgeleerd hebben - niet in alle gevallen, en veelvuldig niet bij bijvoorbeeld pedofiele zedendelinquenten - mogen menen dat zij het delict en de delinquent kunnen doorgronden.

Mij zou kunnen worden tegengeworpen dat ik verouderde denkbeelden aanhang en dat de behandeling meer en meer dienstbaar wordt gemaakt aan het doel van gedragsstructurering. Niettemin gaat deze tegenwerping voorbij aan het gegeven dat zowel aan een ingrijpend behandelingsaanbod als aan een verstrekkende conditioneringsinzet dezelfde diagnose ten grondslag ligt. Over de onderbouwing en houdbaarheid van de diagnose is het mij te doen. Wie kennisneemt van de vele psychiatrische scholen en bijbehorende verschillen in diagnosticering leert dat veelvuldig sprake is van een ijle, vervluchtigde en niet verwortelde, tijdgebonden diagnose. Daarmee is niets mis, de dogmatische instrumenten van de strafrechtsjurist zijn regelmatig hetzelfde oordeel beschoren. De remedie voor beide disciplines is bescheidenheid.

Kortom, de strafrechter moet zich niet te snel laten overtuigen door de redeneringen van de psychiatrisch deskundige. De psychiatrische discipline weet soms onvoldoende inzichtelijk te maken waarom de vaak uitmuntende milieurapportage, de verslagen van de groepsleiding en het psychologisch onderzoek onontkoombaar deze of gene stoornis of gebrek in de ontwikkeling illustreren.

\section{Het gevaar}

Het tweede criterium voor het opleggen of verlengen van de TBS luidt dat betrokkene gevaarlijk moet zijn, in die zin dat het gevaar gerelateerd is aan het plegen van delicten en ontspruit aan een psychische stoornis.

Bij de TBS is het gevaar in concrete gevallen toegespitst op de strafrechtelijk recidive en aan het plegen van een nieuw misdrijf waarvan de ernst kan worden ingeschaald aan de hand van het strafmaximum dat op het gepleegde delict is gesteld.

In dat verband is een recente uitspraak van de Penitentiaire kamer van het Gerechtshof Arnhem relevant. ${ }^{4}$ In casu was de terbeschikkingstelling opgelegd ter 
zake van bedreiging, strafbaar gesteld in artikel 285, eerste lid, van het Wetboek van Strafrecht. Er was slechts sprake van een verbale bedreiging die niet op de een of andere wijze nader was ondersteund en waarvan ook niet aannemelijk was geworden dat die bedreiging ook daadwerkelijk ten uitvoer gelegd zou kunnen worden. Op grond van deze overweging was volgens de Penitentiaire kamer niet voldaan aan het vereiste van artikel 38e, eerste lid van het Wetboek van Strafrecht, zodat deze terbeschikkingstelling diende te eindigen na vier jaar. Anders gezegd, het aan het strafmaximum gerelateerde gevaar was niet ernstig genoeg.

Veel duidelijker ligt de uitkomst indien de kans op herhaling nihil wordt geacht. Recent kreeg ik in de Penitentiaire kamer van het Gerechtshof Arnhem een TBSverlenging onder ogen waarbij de TBS was verlengd omdat de rechtbank bezorgd was over het haalbare karakter van het nazorgtraject door de reclassering. De rechtbank had echter aansluiting gezocht bij de adviezen van de kliniek dat de TBS-gestelde niet langer delictsgevaarlijk was. Indien een dergelijk advies wordt overgenomen is evenwel geen verlenging van de TBS meer mogelijk.

Deze twee zaken illustreren dat de strafrechter juridisch scherp moet toetsen of de behandelaar niet veeleer het behandelperspectief uitvergroot ten nadele van de in de wet vastgelegde criteria. Goed bedoelde en veelal terechte noodzaak tot zorg versus de rechtsbescherming. ${ }^{5}$ De rechter moet scherp toetsen of het behandelperspectief niet binnen de reguliere zorg thuishoort. Zowel bij de BOPZ als bij de TBS dient de rechter zich te realiseren dat sprake is van vrijheidsbeneming die de juridische toets moet kunnen doorstaan. Menselijke ellende hoort thuis in de reguliere geestelijke gezondheidszorg. Dat de rechter in veel opzichten functioneert als een veredelde maatschappelijk werker laat de primaire functie van wetstechnisch controleur onverlet.

Bij de concretisering van het gevaarscriterium rijzen vragen als: waarvoor precies moet er nu gevaar bestaan om in de zin van de wet als gevaar te kunnen worden aangemerkt? En: hoe groot moet dat gevaar zijn (de kansschatting)? Hierbij is de ernst van de stoornis op zichzelf beschouwd niet zo relevant.

Gevaar is in de kern een zeer ingewikkeld begrip. Er is een tegenwoordige stand van zaken (toestand) die eerst gedefinieerd moet worden. Bij die definitie (diagnose) moeten tevens standen van zaken (toestanden) of gangen van zaken (gebeurtenissen) worden beschreven (gedefinieerd) die zich nu reeds in werkelijkheid voordoen en die de grondslag vormen voor de schatting van de kansen op standen en gangen van zaken die zich in de toekomst zullen voordoen. Indien de strafrechter

5 Antoine Mooij, Psychiatrie, recht en de menselijke maat, Amsterdam Meppel 1998, o.a. p. 147. 
het fenomeen gevaar problematiseert, dan doet hij dat om de kans te kunnen schatten dat de verdachte of de TBS-gestelde in de toekomst een bepaald (nader te omschrijven) schadelijke gedraging verricht. Dit immens moeilijke veld van de predictie-problematiek is voor de strafrechter niet of nauwelijks inzichtelijk. Het hangt van de rapporteur af welk inzicht de strafrechter wordt aangereikt. In dat verband is het opmerkelijk dat binnen de gedragswetenschappen wel een standaard wordt gebruikt voor de stoornis (DSM IV), terwijl die voor het gevaar ontbreekt. Het is toe te juichen dat in verschillende TBS-klinieken naar meer standaardisering wordt gestreefd.

Ik keer nog even terug naar de ernst van de stoornis. De ernst-schaal is sterk afhankelijk van het gezichtspunt dat de gedragsdeskundige en de strafrechter hanteren. Zo zal vanuit de behandelbaarheid de ernst heel anders worden benaderd en ingeschaald dan bijvoorbeeld vanuit de mate van desintegratie. Zo kan een dwangneurose nog een redelijke mate van psychische en sociale integratie mogelijk maken in vergelijking met een acute psychose. De behandelbaarheid van een neurose kan daarentegen moeilijker zijn dan die van een acute psychose. Vanuit het integratie-gezichtspunt lijkt de psychose ernstiger, maar vanuit het gezichtspunt van behandelbaarheid niet.

Op dit punt aangekomen, moet me van het hart dat zowel strafrechter als gedragsdeskundige te weinig moeite doen om de kloof tussen beide disciplines te dichten. De deskundige is verplicht zijn bevindingen te vertalen in termen die voor de rechter hanteerbaar zijn. De strafrechter is van zijn kant echter verplicht een gerichte vraagstelling te formuleren. De strafrechter zou ter zitting scherper kunnen en mogen doorvragen naar de diagnosticering van de gedragsdeskundige en de prognotisering van het te verwachten delictsgevaar. Een moeilijkheid is dat de beslissingen van de rechter digitaal van aard zijn. Terwijl de moeiten juist zitten in de overgangssituaties. ${ }^{6}$ Het verdient aanbeveling dat de strafrechter inzake pro justitia rapportages de gedragsdeskundige vaker ter zitting bevraagt dan thans het geval is en indringender dan gebruikelijk is. ${ }^{7}$

In zijn proefschrift heeft $\mathrm{W}$. Nieboer zich veel moeite getroost om tot een helderder afbakening van de relevante onderzoeksvragen over de toerekening te komen (Aegroto suum, dissertatie RUG 1971).

7 Meer in het algemeen in deze zin J. Hielkema, Deskundigen in Nederlandse strafzaken, dissertatie EUR 1996. 


\section{Uitleiding}

Aan veel onderwerpen is hierboven noodgedwongen geen aandacht besteed. Belangrijk werk is bijvoorbeeld verricht in het kader van het interdepartementaal beleidsonderzoek (IBO) naar de instroom van de TBS, op grond waarvan de hoop is uitgesproken dat de multidisciplinaire pro justitia adviezen beter gestructureerd gaan worden. ${ }^{8}$ Niettemin doen deze ontwikkelingen geen afbreuk aan de zorgen rond de verhouding tussen rechter en gedragsdeskundige die onverkort aanwezig zijn.

De strafrechter moet waken tegen pretenties uit de psychiatrie om de patiënt desnoods tot zijn graf te behandelen of te verzorgen, ${ }^{9}$ zonder dat er een "narekenbare" prognose over de stoornis en het delictsgevaar voorhanden is. Zowel strafrechter als gedragsdeskundige past relativering. Het is nog niet zo lang geleden dat veelal vrouwen op grond van een maatregel jarenlang werden behandeld voor kleptomanie. Het verdient aanbeveling dat de strafrechtsjurist niet te snel aanneemt dat er sprake is van een stoornis (zie paragraaf 2) en zich bij het overdenken van de uitwerking van de TBS meer bewust wordt van de proportionaliteits- en subsidiariteitsoverwegingen. Indien de TBS wordt gereserveerd voor een kleiner aantal delinquenten, terwijl de verlengingsbeslissing met nog grotere zorg wordt omkleed, is er al veel gewonnen.

Thans zien wij de zorgelijke ontwikkeling dat de doorsnee burger bang is voor en verontwaardigd met name over zeden- en geweldsdelicten, bij uitstek de delicten waarvoor TBS wordt opgelegd. De gedragsdeskundige spiegelt in dergelijke zaken de strafrechter veelvuldig een behandelbaarheid van de verdachte voor, en bij afwezigheid daarvan een definitief ogende verwijdering uit de samenleving door middel van de verblijfsafdelingen. De diagnose lijkt doordacht en wordt vergezeld van gepaste medische terminologie. De prognosticering van gevaar wordt regelmatig in algemeenheden gesteld, die niettemin sporen met onderhuidse angsten. We moeten ons scherp voor ogen houden dat het de strafrechter is en niemand anders die bepaalt of deze maatregel kan worden opgelegd en bepaalt of de verlenging van de TBS-maatregel plaatsvindt. Het is de taak van de strafrechter met de grootst mogelijke zorg te toetsen of de toepassing van de TBS niet te schielijk plaatsvindt.

8 Over stromen. In-, door- en uitstroom bij de TBS, Rapport IBO TBS, Den Haag 1998.

9 A.W.M. Mooij, Gevaar, gevaarlijk, gevaarlijkheid, Delikt en Delinkwent 2000, pp. 21-30. 